\title{
NON-PARAMETRIC STABILITY ANALYSIS OF SUNFLOWER OIL YIELD TRIALS
}

\author{
Balalić, I. ${ }^{*}$, Zorić, M. $^{2}$, Miklič, V. ${ }^{1}$, Dušanić, N. ${ }^{1}$, \\ Terzić, S. ${ }^{1}$, and Radić, V. ${ }^{1}$ \\ ${ }^{1}$ Institute of Field and Vegetable Crops, Oil Crops Department, \\ Maksima Gorkog 30, 21000 Novi Sad, Republic of Serbia \\ ${ }^{2}$ Faculty of Technology, University of Novi Sad, \\ Bulevar Cara Lazara 1, 21000 Novi Sad, Republic of Serbia
}

Received: March 29, 2011

Accepted: June 10, 2011

\section{SUMMARY}

A three-year experiment $(2008,2009,2010)$ on twenty sunflower hybrids grown in 13 (2010) to $15(2009,2008)$ locations in the region of Vojvodina and central Serbia was carried out in order to study GEI (genotype $\times$ environment interaction) on oil yield and stability of hybrids using non-parametric measures of stability. The non-parametric test indicated the presence of significant crossover interaction $[\mathrm{G}(\mathrm{E})$ and $\mathrm{E}(\mathrm{G})]$. Non-parametric measures $\mathrm{S}_{\mathrm{i}}{ }^{(1)}$ and $\mathrm{S}_{\mathrm{i}}{ }^{(2)}$ were used to determine stability of sunflower hybrids. The level of association among stability measures was assessed using Sperman's rank correlation. Significant differences in rank stability among 20 sunflower hybrids grown in 13 (2010) or $15(2009,2008)$ locations were found. According to non-parametric stability parameters $\mathrm{S}_{\mathrm{i}}{ }^{(1)}$ and $\mathrm{S}_{\mathrm{i}}{ }^{(2)}$, hybrids Baća and Vranac were most stable in all locations. Baća also had high oil yield in 2008 and 2009. In 2010 two new hybrids (NS-H-6612, NS-H-2069) were high yielding and stable for oil yield. Hybrid NS-H-111 was also stable in all locations in 2009 and 2010 and its oil yield was above average.

The Spearman's rank correlation between non-parametric stability parameters, showed highly significant $(\mathrm{P}<0.01)$ rank correlations between $\mathrm{S}_{\mathrm{i}}{ }^{(1)}$ and $\mathrm{S}_{\mathrm{i}}{ }^{(2)}$, indicating that the two measures were similar in classifying the hybrids according to their stability under different environmental (location) conditions.

Non-parametric measures of stability, based on ranks, could be recommended to agronomists and plant breeders.

Key words: sunflower, oil yield, crossover interaction, non-parametric stability analysis

* Correspondinf author: Phone: ++381 214898 402; Fax: ++381216413 833; e-mail: igor.balalic@ifvens.ns.ac.rs 


\section{INTRODUCTION}

Oil yield, the primary indicator of sunflower productivity, depends on seed yield and seed oil content (Škorić et al., 2005). High and stable oil yield is a very desirable attribute of sunflower (Helianthus annuus L.) hybrids. Stable yield of a hybrid means that its rank relative to other hybrids remains unchanged in a given environment; i.e., maximum stability occurs with equal ranks in different environments. A hybrid is considered adaptive or stable if it has a high mean yield, but a low degree of fluctuation in yielding ability when grown in diverse environments (Arshad et al., 2003, Tuba and Dogan, 2006).

Genotype $\times$ environment interaction (GEI) is a major problem in the comparison of genotype performance across environments (Kang, 1990). The researches very often ignore GEI in their recommendation for hybrid growing. It is necessary to use corresponding statistical procedures for the efficient evaluation of interaction.

Interaction among genotypes and environment can be studied and interpreted by a wide variety of statistic models and methodologies (Crossa, 1990). The nonparametric models, which do not presuppose assumptions, as normal distrubution, homogenity of variances and additivity or linearity of genotypic and environmental effects, are not so often used in agronomy, crop science and plant breeding (Hühn and Leon, 1995), although these methods are easy to use and interpret (Hühn, 1990a).

The method of Van der Laan - de Kroon (de Kroon and Van der Laan, 1981) defines interactions according to the crossover interaction (COI) model (Baker, 1988). This method requires rank orders for each environment of each genotype separately. According to Truberg and Hühn (2000), non-parametric statistical procedures for the test of crossover interactions were developed in the field of medicine and can also be applied to GEI in multi-environment trials (MET).

Measurement and evaluation of phenotypic stability in different environments is of importance in production and plant breeding. Non-parametric methods proposed by Hühn (1979), Nassar and Hühn (1987), Kang (1988), Fox et al. (1990) and Thennarasu (1995) are based on ranks of genotypes in each environment, and genotypes with similar rankings across environments are classified as stable. Hühn (1979) and Nassar and Hühn (1987) proposed three different non-parametric measures of stability $\mathrm{S}_{\mathrm{i}}{ }^{(1)}$ (the mean of the absolute rank differences of a genotype over $n$ environments), $\mathrm{S}_{\mathrm{i}}{ }^{(2)}$ (the variance among the ranks over the $n$ environments) and $S_{i}{ }^{(3)}$ (the sum of square deviations in yield units of each classification relative to the mean classification). Each of them can be used as a stability parameter. Approximate test of significance based on the normal distribution was developed by Nassar and Hühn (1987) and Truberg and Hühn (2000) for $\mathrm{S}_{\mathrm{i}}^{(1)}$ and $\mathrm{S}_{\mathrm{i}}{ }^{(2)}$.

The objectives of this study were to test the presence of interaction for oil yield in MET, to determine phenotypic stability of sunflower hybrids and to evaluate the level of association among non-parametric stability parameters. 


\section{MATERIALS AND METHODS}

\section{Plant material and field conditions}

The study was carried out with 20 sunflower hybrids in 15 locations in 2008 and 2009, and 13 locations in 2010. In 2008 and 2009 the experimental hybrids were: NS-H-45, Vranac, Milan, Bačvanin, NS-H-111, Velja, Krajišnik, Perun, Pobednik, Baća, Sremac, Somborac, Šumadinac, Kazanova, Vladimir, Plamen, Duško, Branko, Novosadjanin, Oliva, and the locations: Rimski Šančevi, Šupljak, Bačka Topola, Sombor, Kljajićevo, Kikinda, Zrenjanin, Pančevo, Vršac, Donji Petrovci, Krčedin, Neštin, Kula Vitovnica, Negotin, Zaječar. In 2010 hybrids were: Duško, Novosadjanin, Sremac, NS-H-111, Vladimir, Baća, Branko, Velja, Banaćanin, Šumadinac, Oskar, Orfej, Orion, NS-H-6032, NS-H-6033, NS-H-6206, NS-H-2069, NS-H-6578, NS-H-6376, NS-H-6612, and locations: Vrbas, Senta, Šupljak, Sombor, Aleksa Šantić, Pančevo, Vršac, Krčedin, Neštin, Kuzmin, Kula Vitovnica, Negotin, Zaječar.

The results of oil yield were obtained from a network of small plot trials in Vojvodina and in central Serbia. Twenty sunflower hybrids were planted in a randomized complete block design with four replications in all the locations during 2008-2010. The experimental plots consisted of four replications. To reduce border effects, data for oil yield were taken from the middle two rows of each plot. The elementary plot size was $13.3 \mathrm{~m}^{2}$. During the vegetation period optimal agro-engineering was applied. Oil yield, as a product of grain yield and oil concentration, was expressed in $\mathrm{t} \mathrm{ha}^{-1}$.

\section{Statistical analysis}

The non-parametric statistical procedure of de Kroon and Van der Laan (1981) was used to test the significance of crossover interaction (Hühn and Leon, 1995). This method defines interaction according to the crossover interaction model (Baker, 1988). Interactions exist if rank orders of genotypes (hybrids, cultivars) are different in different environments, denoted by $\mathrm{G}(\mathrm{E})$, or if rank orders of environments are different in different genotypes, denoted by $E(G)$. This method transforms the original data into ranks and analyze the rank orders. The value of genotype $i$ in environment $j$ and replication $k$ is denoted by:

$\mathrm{X}_{\mathrm{ijk}}(\mathrm{i}=1,2, \ldots \mathrm{i} ; \mathrm{j}=1,2, \ldots \mathrm{m} ; \mathrm{k}=1,2, \ldots \mathrm{n})$

The test statistics for crossover interactions is approximately $\chi^{2}$ distributed with (l-1) $\times(\mathrm{m}-1)$ degrees of freedom, where $l$ is the number of genotypes, a and $m$ the number of environments (Hühn and Leon, 1995):

$$
\chi^{2}(\mathrm{G} \times \mathrm{E})=12 / \mathrm{ln}^{2}(\ln +1) \times\left(\sum_{\mathrm{i}=1}^{1} \sum_{\mathrm{j}=1}^{\mathrm{m}} \mathrm{R}_{\mathrm{ij}}^{2} .-1 / \mathrm{m} \sum_{\mathrm{i}=1}^{1} \mathrm{R}_{\mathrm{i}}^{2} . .\right)
$$

The statistical procedures used for stability analysis of genotypes were proposed by Nassar and Hühn, 1987; Hühn and Nassar, 1989. From the nonparamet- 
ric stability model $\mathrm{S}_{\mathrm{i}}^{(1)}$ the mean of the absolute rank differences of a genotype over the $\mathrm{N}$ environments, was expressed as:

$$
S_{i}^{(1)}=2 \sum_{j=1}^{N-1} \sum_{j=j+1}^{N-1}\left|r_{i j}-r_{i j}\right| /[N(N-1)]
$$

where $\mathrm{r}_{\mathrm{ij}}=$ rank of cultivar $i$ in environment $j$.

$\mathrm{S}_{\mathrm{i}}{ }^{(2)}$, the variance among the ranks over $\mathrm{N}$ environments, was expressed as:

$\mathrm{S}_{\mathrm{i}}^{(2)}=\sum_{\mathrm{j}=1}^{\mathrm{N}}\left(\mathrm{r}_{\mathrm{ij}}-\overline{\mathrm{r}}_{\mathrm{i} .}\right)^{2} / \mathrm{N}-1$

Where $r_{i .}=\sum_{j=1}^{N} r_{i j} / N$.

Genotype $i$ is considered to be stable in different environments if its rank is similar in these environments. For a genotype with maximum stability, $S_{i}{ }^{(1)}=0$; likewise zero variance $\left(\mathrm{S}_{\mathrm{i}}{ }^{(2)}=0\right)$ also indicates maximum stability.

The significance tests for $\mathrm{S}_{\mathrm{i}}^{(1)}$ and $\mathrm{S}_{\mathrm{i}}{ }^{(2)}$ were made according to Nassar and Hühn (1987) and Hühn (1990a):

$\mathrm{Z}_{\mathrm{i}}^{(\mathrm{m})}=\left\{\mathrm{S}_{\mathrm{i}}^{(\mathrm{m})}-\mathrm{E}\left(\mathrm{S}_{\mathrm{i}}{ }^{(\mathrm{m})}\right)\right\}^{2} / \mathrm{V} \mathrm{S}_{\mathrm{i}}^{(\mathrm{m})}, \mathrm{m}=1.2$.

$\mathrm{S}_{\mathrm{i}}^{(\mathrm{m})}=$ expected value

This has an approximate $\chi^{2}$-distribution with one degree of freedom and the statistic may be a chisquared distribution with $\mathrm{K}$ degrees of freedom with $\mathrm{E}\left(\mathrm{S}_{\mathrm{i}}{ }^{(\mathrm{m})}\right)=\operatorname{expectation}(=$ mean $)$ of $\mathrm{S}_{\mathrm{i}}^{(\mathrm{m})}$ and $\mathrm{V}\left(\mathrm{S}_{\mathrm{i}}{ }^{(\mathrm{m})}\right)=$ variance of $\left.\mathrm{S}_{\mathrm{i}}{ }^{(\mathrm{m})}\right)$.

$$
\mathrm{S}^{(\mathrm{m})}=\sum_{\mathrm{i}=1}^{\mathrm{K}} \mathrm{Z}_{\mathrm{i}}^{(\mathrm{m})}, \mathrm{m}=1,2
$$

The stability parameters, $\mathrm{S}_{\mathrm{i}}{ }^{(1)}$ and $\mathrm{S}_{\mathrm{i}}{ }^{(2)}$, were compared using Spearman's rank correlation (Steel and Torrie, 1980).

\section{RESULTS AND DISCUSSION}

\section{Analysis of hybrid $\times$ location interaction}

Genotype (hybrid, cultivar) interaction with environmental factors (location, year of growing, sowing date, soil type etc.) is an important consideration for crop production and plant breeding. The effects that genotypes and environments have on genotype $\times$ environmental interactions are statistically non-additive, indicating that differences in yields depend on the environment (Yue et al., 1997).

ANOVA for oil yield showed that hybrids, locations and hybrid $\times$ location interaction were highly significant (data not shown). The significant GEI indicated that the responses of the hybrids changed depending on the environmental conditions.

Analysis of COI using the non-parametric procedure of de Kroon and van der Laan (1981) showed that for all individual years of experiment, significant crosso- 
ver interaction of both $G(E)$ and $E(G)$, with the preponderance of $E(G)$ on oil yield in sunflower were found (Table1). This result is in agreement with findings of Ceccarelli and Grando (1991) in barley. Sabagna et al. (2006) also reported highly significant COI in lentil genotypes, investigating grain yield. Using the same method, Mohammadi et al. (2007) reported highly significant COI in 20 winter wheat genotypes growing in 18 environments.

Table 1: Nonparametric tests of COI- $\chi^{2}$ values of de Kroon-van der Laan method over years of investigation

\begin{tabular}{lcccc}
\hline \multirow{2}{*}{ Year } & df & $\chi^{2}$ & \multicolumn{2}{c}{$\chi^{2}$} \\
\cline { 4 - 5 } & & $644.40^{\star \star}$ & $168.45^{\star \star}$ & $475.95^{\star \star}$ \\
2008 & 323 & $570.46^{\star \star}$ & $202.28^{\star \star}$ & $368.18^{\star *}$ \\
2010 & 266 & $483.09^{\star \star}$ & $112.11^{\star \star}$ & $370.98^{\star *}$ \\
\hline
\end{tabular}

$\star \star P<0.01$

The magnitude of interaction shows the influence of environmental factors on adaptability and stability, which is desired character only when it is connected with yield above average (Yan and Hunt, 2003).

Table 2: Mean oil yield ( $\mathrm{ha}^{-1}$ ), estimation and test of nonparametric stability measures for sunflower hybrids across environments (2008)

\begin{tabular}{|c|c|c|c|c|c|c|c|}
\hline $\mathrm{Nr}$. & Hybrid & Oil yield & Mean rank & $\mathrm{S}_{\mathrm{i}}^{\left({ }^{(1)}\right.}$ & $Z_{i}^{(1)}$ & $\mathrm{S}_{\mathrm{i}}^{(2)}$ & $\mathrm{Z}_{\mathrm{i}}^{(2)}$ \\
\hline 1 & NS-H-45 & 1.35 & 4.3 & 4.28 & 9.23 & 17.01 & 4.71 \\
\hline 2 & Vranac & 1.44 & 5.6 & 4.27 & 9.31 & 14.97 & 5.97 \\
\hline 3 & Milan & 1.60 & 12.2 & 5.32 & 2.90 & 22.18 & 2.19 \\
\hline 4 & Bačvanin & 1.58 & 10.9 & 6.17 & 0.39 & 27.46 & 0.60 \\
\hline 5 & NS-H-111 & 1.63 & 12.7 & 6.19 & 0.35 & 29.04 & 0.32 \\
\hline 6 & Velja & 1.63 & 12.9 & 6.17 & 0.38 & 28.58 & 0.39 \\
\hline 7 & Krajišnik & 1.56 & 9.6 & 5.50 & 2.18 & 22.52 & 2.05 \\
\hline 8 & Perun & 1.50 & 7.4 & 5.94 & 0.83 & 27.19 & 0.66 \\
\hline 9 & Pobednik & 1.65 & 12.7 & 6.92 & 0.12 & 35.09 & 0.06 \\
\hline 10 & Baća & 1.69 & 15.3 & 5.22 & 3.39 & 22.24 & 2.17 \\
\hline 11 & Sremac & 1.57 & 9.9 & 6.50 & 0.04 & 31.70 & 0.04 \\
\hline 12 & Somborac & 1.60 & 11.7 & 7.72 & 1.87 & 42.97 & 1.69 \\
\hline 13 & Šumadinac & 1.63 & 12.0 & 6.06 & 0.58 & 26.60 & 0.79 \\
\hline 14 & Kazanova & 1.59 & 10.9 & 5.29 & 3.03 & 20.93 & 2.71 \\
\hline 15 & Vladimir & 1.64 & 12.4 & 5.42 & 2.50 & 21.64 & 2.41 \\
\hline 16 & Plamen & 1.61 & 11.7 & 5.69 & 1.51 & 24.33 & 1.42 \\
\hline 17 & Duško & 1.65 & 13.1 & 6.25 & 0.27 & 30.81 & 0.11 \\
\hline 18 & Branko & 1.54 & 8.4 & 6.12 & 0.46 & 30.37 & 0.15 \\
\hline 19 & Novosadjanin & 1.53 & 9.2 & 6.56 & 0.01 & 32.15 & 0.02 \\
\hline \multirow[t]{3}{*}{20} & Oliva & 1.49 & 7.2 & 6.92 & 0.12 & 38.15 & 0.43 \\
\hline & Sum & & & & 39.49 & & 28.88 \\
\hline & $\begin{array}{l}E\left(S_{i}^{(1)}\right)=6.65 \\
E\left(S_{i}^{(2)}\right)=33.25\end{array}$ & & $\begin{array}{l}\operatorname{Var} S_{i}^{(1)}=0 \\
\operatorname{Var} S_{i}^{(2)}=5\end{array}$ & & $\begin{array}{l}Z_{i}^{(1)}, Z \\
\text { sum }=3\end{array}$ & & \\
\hline
\end{tabular}




\section{Stability analysis}

The results of non-parametric stability measures, $\mathrm{S}_{\mathrm{i}}^{(1)}$ and $\mathrm{S}_{\mathrm{i}}^{(2)}$, are based on values of the sunflower hybrids across locations and they give equal weight to each location. According to Becker and Leon (1988) genotypes with fewer changes in rank are considered to be more stable. The $\mathrm{S}_{\mathrm{i}}{ }^{(1)}$ estimates are based on all possible pair-wise rank differences, while $\mathrm{S}_{\mathrm{i}}{ }^{(2)}$ is based on variances of ranks for each genotype across environments (Nassar and Hühn, 1987; Hühn and Nassar, 1989). These two statistics ranked sunflower hybrids similarly for stability. Maximum stability of a genotype $S_{i}^{(1)}=0$ and zero variance $S_{i}^{(2)}$ are the indicator of maximum stability (Hühn, 1990a). According to $\mathrm{S}_{\mathrm{i}}{ }^{(1)}$ and $\mathrm{S}_{\mathrm{i}}{ }^{(2)}$, Vranac (2), NS-H-45 (1) and Baća (10) in 2008 had the smallest changes in ranks and are thus regarded as the most stable hybrids. Hybrid Somborac (12) was most unstable (Table 2). $\mathrm{S}_{\mathrm{i}}{ }^{(1)}$ and $\mathrm{S}_{\mathrm{i}}{ }^{(2)}$ of the tested hybrids in 2009 showed that hybrids Vranac (2), Šumadinac (13), Duško (17) and Baća (10) had the lowest values. Therefore, these hybrids were regarded as the most stable. On the other hand, hybrids Bačvanin (4), Kazanova (14) and Velja (6), with the highest $S_{i}{ }^{(1)}$ and $S_{i}{ }^{(2)}$ values, were determined to be unstable in 2009 (Table 3).

Table 3: Mean oil yield ( $\mathrm{ha}^{-1}$ ), estimation and test of nonparametric stability measures for sunflower hybrids across environments (2009)

\begin{tabular}{|c|c|c|c|c|c|c|c|}
\hline Nr. & Hybrid & Oil yield & Mean rank & $\mathrm{S}_{\mathrm{i}}^{\left({ }^{(1)}\right.}$ & $Z_{i}^{(1)}$ & $\mathrm{S}_{\mathrm{i}}^{(2)}$ & $Z_{i}^{(2)}$ \\
\hline 1 & NS-H-45 & 1.42 & 5.5 & 4.93 & 3.89 & 19.55 & 2.72 \\
\hline 2 & Vranac & 1.33 & 3.1 & 2.55 & 22.17 & 5.12 & 11.46 \\
\hline 3 & Milan & 1.50 & 8.3 & 6.48 & 0.04 & 31.35 & 0.05 \\
\hline 4 & Bačvanin & 1.55 & 11.2 & 7.24 & 0.46 & 37.60 & 0.27 \\
\hline 5 & NS-H-111 & 1.66 & 14.8 & 4.68 & 5.14 & 16.32 & 4.15 \\
\hline 6 & Velja & 1.52 & 10.3 & 7.10 & 0.27 & 36.92 & 0.20 \\
\hline 7 & Krajišnik & 1.52 & 9.5 & 5.54 & 1.62 & 21.98 & 1.84 \\
\hline 8 & Perun & 1.51 & 8.2 & 5.63 & 1.38 & 22.92 & 1.55 \\
\hline 9 & Pobednik & 1.65 & 13.9 & 6.75 & 0.01 & 34.44 & 0.02 \\
\hline 10 & Baća & 1.61 & 13.3 & 4.36 & 6.91 & 14.95 & 4.85 \\
\hline 11 & Sremac & 1.54 & 10.6 & 5.91 & 0.71 & 27.02 & 0.56 \\
\hline 12 & Somborac & 1.64 & 14.2 & 5.07 & 3.31 & 18.60 & 3.11 \\
\hline 13 & Šumadinac & 1.40 & 5.0 & 3.31 & 14.69 & 8.02 & 9.22 \\
\hline 14 & Kazanova & 1.61 & 13.1 & 7.14 & 0.32 & 38.64 & 0.42 \\
\hline 15 & Vladimir & 1.55 & 10.8 & 6.16 & 0.31 & 27.75 & 0.44 \\
\hline 16 & Plamen & 1.52 & 8.8 & 4.91 & 3.98 & 17.60 & 3.55 \\
\hline 17 & Duško & 1.64 & 14.1 & 3.81 & 10.65 & 10.92 & 7.22 \\
\hline 18 & Branko & 1.60 & 13.2 & 5.01 & 3.55 & 18.13 & 3.31 \\
\hline 19 & Novosadjanin & 1.67 & 15.2 & 5.47 & 1.85 & 23.74 & 1.31 \\
\hline \multirow[t]{3}{*}{20} & Oliva & 1.44 & 7.0 & 5.98 & 0.59 & 27.57 & 0.47 \\
\hline & Sum & & & & 81.86 & & 56.70 \\
\hline & $\begin{array}{l}E\left(S_{i}^{(1)}\right)=6.65 \\
E\left(S_{i}^{(2)}\right)=33.25\end{array}$ & & $\begin{array}{l}\operatorname{Var} S_{i}^{(1)} \\
\operatorname{Var} S_{i}^{(2)}\end{array}$ & & $\begin{array}{l}2 Z_{i}^{(1)}, Z \\
2_{\text {sum }}=3\end{array}$ & & \\
\hline
\end{tabular}


In 2010, NS-H-6612 (20), Sremac (3) and NS-H-2069 (17) had the smallest changes in ranks, so they were most stable, while Oskar (11) was most unstable (Table 4).

Table 4: Mean oil yield ( $\mathrm{ha}^{-1}$ ), estimation and test of nonparametric stability measures for sunflower hybrids across environments (2010)

\begin{tabular}{|c|c|c|c|c|c|c|c|}
\hline Nr. & Hybrid & Oil yield & Mean rank & $\mathrm{S}_{\mathrm{i}}^{\left({ }^{(1)}\right.}$ & $Z_{i}^{(1)}$ & $\mathrm{S}_{\mathrm{i}}^{(2)}$ & $\mathrm{Z}_{\mathrm{i}}^{(2)}$ \\
\hline 1 & Duško & 1.31 & 13.2 & 6.18 & 0.24 & 29.36 & 0.19 \\
\hline 2 & Novosadjanin & 1.22 & 8.2 & 5.18 & 2.38 & 20.47 & 2.00 \\
\hline 3 & Sremac & 1.21 & 8.0 & 3.51 & 10.85 & 9.04 & 7.17 \\
\hline 4 & NS-H-111 & 1.31 & 13.6 & 5.54 & 1.36 & 24.49 & 0.94 \\
\hline 5 & Vladimir & 1.18 & 7.5 & 5.56 & 1.30 & 22.92 & 1.31 \\
\hline 6 & Baća & 1.28 & 10.9 & 8.73 & 4.77 & 60.37 & 9.00 \\
\hline 7 & Branko & 1.13 & 5.7 & 5.90 & 0.62 & 37.73 & 0.25 \\
\hline 8 & Velja & 1.23 & 9.7 & 7.56 & 0.92 & 40.56 & 0.65 \\
\hline 9 & Banaćanin & 1.29 & 11.6 & 6.72 & 0.01 & 32.24 & 0.01 \\
\hline 10 & Šumadinac & 1.23 & 8.3 & 5.58 & 1.27 & 22.06 & 1.53 \\
\hline 11 & Oskar & 1.22 & 8.9 & 7.72 & 1.26 & 43.58 & 1.31 \\
\hline 12 & Orfej & 1.27 & 10.5 & 4.40 & 5.60 & 13.83 & 4.61 \\
\hline 13 & Orion & 1.23 & 9.0 & 6.13 & 0.30 & 27.67 & 0.38 \\
\hline 14 & NS-H-6032 & 1.23 & 9.1 & 7.28 & 0.44 & 37.41 & 0.21 \\
\hline 15 & NS-H-6033 & 1.23 & 9.0 & 6.64 & 0.00 & 31.44 & 0.04 \\
\hline 16 & NS-H-6206 & 1.30 & 12.1 & 5.27 & 2.10 & 21.17 & 1.79 \\
\hline 17 & NS-H-2069 & 1.33 & 14.5 & 4.18 & 6.73 & 12.44 & 5.30 \\
\hline 18 & NS-H-6578 & 1.34 & 13.6 & 6.41 & 0.06 & 35.42 & 0.06 \\
\hline 19 & NS-H-6376 & 1.24 & 9.4 & 6.10 & 0.33 & 27.26 & 0.44 \\
\hline \multirow[t]{3}{*}{20} & NS-H-6612 & 1.42 & 17.3 & 2.82 & 16.17 & 6.44 & 8.80 \\
\hline & Sum & & & & 56.73 & & 45.99 \\
\hline & $\begin{array}{l}E\left(S_{i}^{(1)}\right)=6.65 \\
E\left(S_{i}^{(2)}\right)=33.25\end{array}$ & & $\begin{array}{l}\operatorname{Var} S_{i}^{(1)}=0 \\
\operatorname{Var} S_{i}^{(2)}=8\end{array}$ & & $\begin{array}{l}l^{2} Z_{i}^{(1)}, \\
l^{2} \text { sum }=3\end{array}$ & & \\
\hline
\end{tabular}

For practical applications Hühn (1990a) preferred the use of $S_{i}{ }^{(1)}$ against $S_{i}{ }^{(2)}$. This stability parameter is very easy to compute and allows a clear and relevant interpretation (mean absolute difference between environments). In addition to this, an efficient test of significance is also available.

In the significance tests for $\mathrm{S}_{\mathrm{i}}^{(1)}$ and $\mathrm{S}_{\mathrm{i}}^{(2)}$, developed by Nassar and Hühn (1987), $Z_{i}^{(1)}$ and $Z_{i}^{(2)}$ values were based on the ranks of adjusted data and added for hybrids to obtain $Z$ values. Since $Z_{i}^{(1)}$ sum=39.49 was higher than the critical value of $\chi^{2}=31.41$, there were significant differences in rank stability among 20 sunflower hybrids grown in 15 locations during 2008 (Table 2).

Significant differences in rank stability among 20 hybrids across 15 locations occurred in 2009 (Table 3) since both of the these values $Z_{i}^{(1)}$ sum $=81.86$ and $Z_{i}^{(2)}$ sum $=56.70$ were higher than the critical value $\chi^{2}=31.41$. A similar situation was observed in 2010. Namely, both $Z_{i}^{(1)}$ and $Z_{i}^{(2)}$ sum were higher than the critical 
$\chi^{2}$, so it can be concluded that there were highly significant differences in rank stability among 20 hybrids grown in 13 locations (Table 4).

Graphs of mean oil yield $\left(t \mathrm{ha}^{-1}\right)$ vs. non-parametric measures $\mathrm{S}_{\mathrm{i}}{ }^{(1)}$ and $\mathrm{S}_{\mathrm{i}}{ }^{(2)}$ could enhance visual efficiency of sunflower hybrid recommendations on genotype by location interaction. Mean $\mathrm{S}_{\mathrm{i}}{ }^{(1)}$ and $\mathrm{S}_{\mathrm{i}}{ }^{(2)}$ values and grand mean oil yield divided (Figures 1 and 2) into four sections. In section 1, the hybrids have high oil yield and small $\mathrm{S}_{\mathrm{i}}{ }^{(1)}$ and $\mathrm{S}_{\mathrm{i}}{ }^{(2)}$ values; section 2 includes the hybrids with high oil yield and large $S_{i}{ }^{(1)}$ and $S_{i}{ }^{(2)}$ values; section 3 presents the hybrids with low oil yield and large $S_{i}{ }^{(1)}$ and $S_{i}{ }^{(2)}$ values and, section 4 are the hybrids with low oil yield and small $\mathrm{S}_{i}{ }^{(1)}$ and $\mathrm{S}_{i}{ }^{(2)}$ values. A stable hybrid is the one that provides high yield and consistent performance across locations. According to this definition, only sunflower hybrids in section 1 can be considered stable with high oil yield. In 2008 the hybrid Baća (10), with highest average oil yield, was most stable, adapted to all locations. The hybrids Vladimir (15), Plamen (16), Milan (3) and Kazanova (14) were also stable and with oil yield above average. In 2009 section 1 included the hybrids Baća (10), Duško (17) and NS-H-111 (5), with the highest oil yield and Somborac (12) and Branko (18) which were also stable. In 2010 the most stable, with oil yield above average, were hybrids NS-H-6612 (20), NS-H-2069 (17), Orfej (12), NS-H6206 (16) and NS-H-111 (4), Figures 1 and 2.

Seasonal fluctuations which are related to moisture availability, temperature and occurrence of insects and diseases could cause GEI thus complicating the recommendation of hybrids or interpretation of the data (Yue et al., 1996).

Table 5: Spearman's rank correlations between nonparametric stability parameters for oil yield of 20 sunflower hybrids grown in 13 to 15 locations

\begin{tabular}{lc}
\hline Year & $\mathrm{S}_{\mathrm{i}}{ }^{(1)} v s . \mathrm{S}_{\mathrm{i}}{ }^{(2)}$ \\
\hline 2008 & $0.978^{\star \star}$ \\
2009 & $0.989^{\star \star}$ \\
2010 & $0.947^{\star \star}$ \\
\hline
\end{tabular}

\section{Relationship between stability parameters}

The Spearman's rank correlation between non-parametric stability parameters showed highly significant $(\mathrm{P}<0.01)$ rank correlations between $\mathrm{S}_{\mathrm{i}}^{(1)}$ and $\mathrm{S}_{\mathrm{i}}{ }^{(2)}$, indicating that the two measures were similar in classifying the hybrids according to their stability under different environmental (location) conditions (Table 5). These parameters classified sunflower hybrids as stable or unstable in similar way. Hühn (1990b) reported that the parameters $\mathrm{S}_{\mathrm{i}}{ }^{(1)}$ and $\mathrm{S}_{\mathrm{i}}{ }^{(2)}$ were nearly perfectly associated in 1975 and 1976, while in 1974 this correlation was intermediate for grain yield in winter wheat. The same results, high correlations between stability parameters, were obtained by Yue et al. (1996) in alfalfa, Scapim et al. (2000) and Delic et al. (2009), in maize, Sabagna et al. (2006) in lentil, Mohammadi et al. (2007) and Akcura et al. (2009) in durum wheat, Akcura and Kaya (2008) in wheat and Segerloo et al. (2008) in chickpea. 

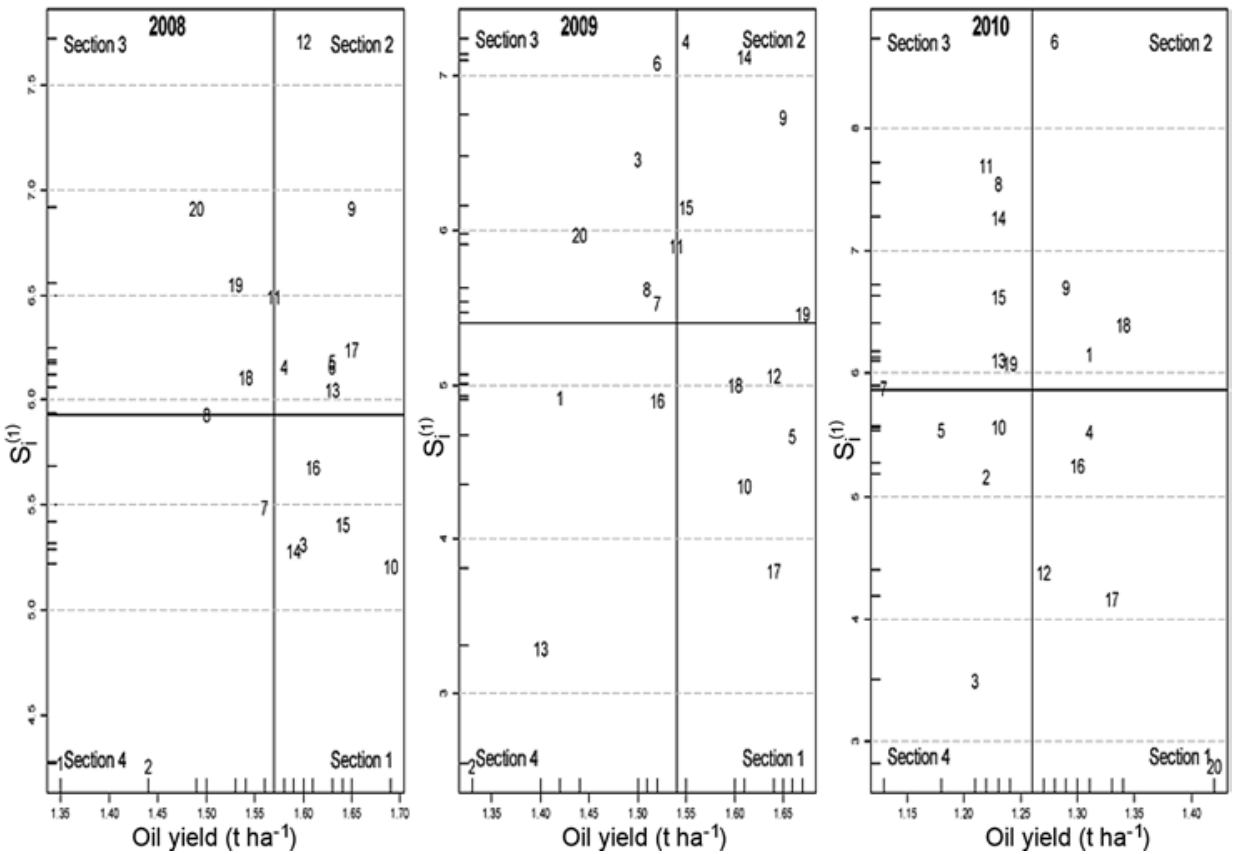

Figure 1: Plot of $S_{i}^{(1)}$ vs. mean oil yield $\left(t h a^{-1}\right)$ for sunflower hybrids over locations
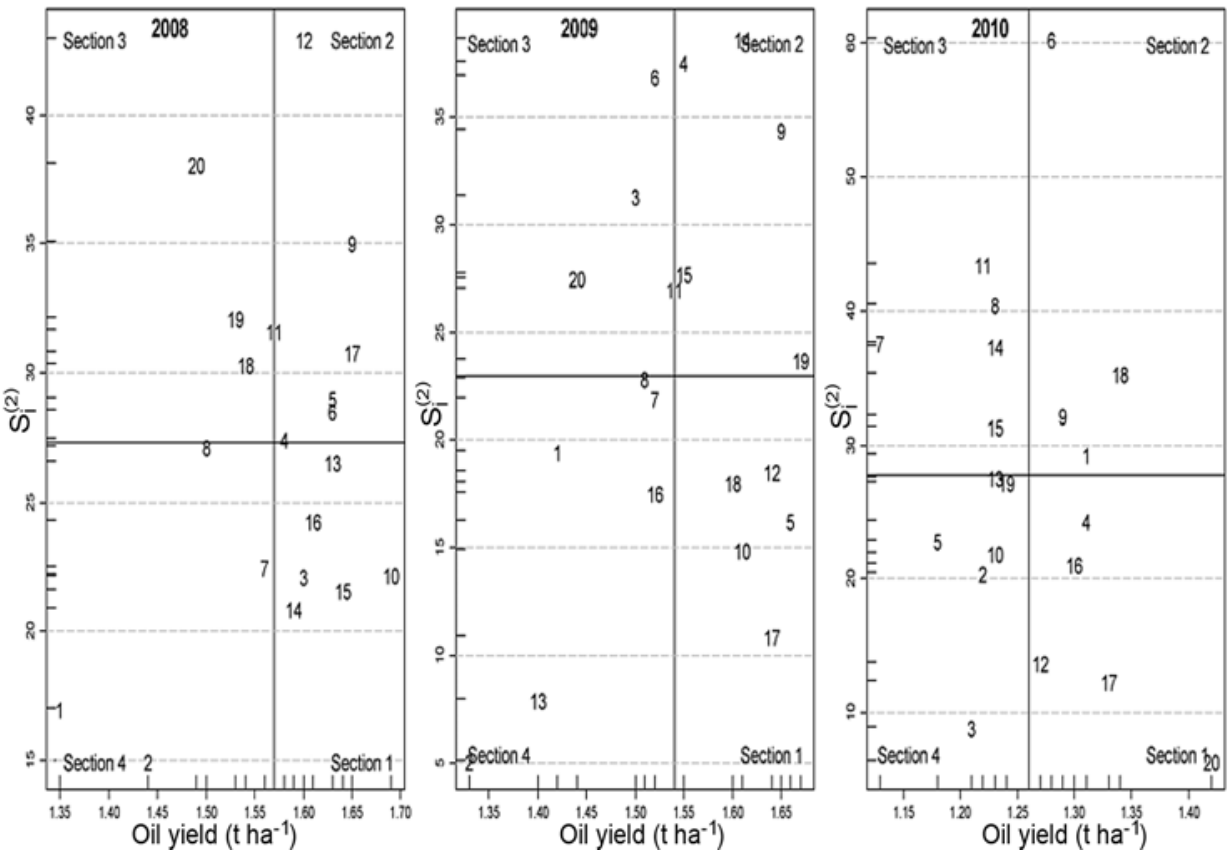

Figure 2: Plot of $S_{i}^{(2)}$ vs. mean oil yield ( $\left.t \mathrm{ha}^{-1}\right)$ for sunflower hybrids over locations 


\section{CONCLUSION}

The results from the study suggested that a significant COI existed between 20 sunflower hybrids grown in $13(2010)$ to $15(2009,2008)$ locations for oil yield in sunflower. The presence of GEI suggests high oil yielding sunflower hybrids which are stable in different locations.

Significant differences in rank stability among 20 sunflower hybrids grown in 13 (2010) or 15 (2009, 2008) locations were found. According to nonparametric stability parameters $\mathrm{S}_{\mathrm{i}}{ }^{(1)}$ and $\mathrm{S}_{\mathrm{i}}{ }^{(2)}$, hybrids Baća and Vranac were the most stable in all locations and Baća also had high oil yield in 2008 and 2009. In 2010 two new hybrids (NS-H-6612, NS-H-2069) were high yielding and stable for oil yield. Hybrid NS-H-111 was also stable in all tested locations in 2009 and 2010 and it had oil yield above average, showing broader adaptability. We recommend plotting the mean oil yield against $\mathrm{S}_{\mathrm{i}}^{(1)}$ and $\mathrm{S}_{\mathrm{i}}{ }^{(2)}$ stability measures in order to choose sunflower hybrids with high oil yield and low $\mathrm{S}_{\mathrm{i}}{ }^{(1)}$ and $\mathrm{S}_{\mathrm{i}}{ }^{(2)}$ values.

The parameters $\mathrm{Si}^{(1)}$ and $\mathrm{Si}^{(2)}$ were nearly perfectly associated in 2008, 2009 and 2010, with numerical values between 0.947 (2010) and 0.989 (2009).

Non-parametric measures of stability based on ranks could be used by agronomists and plant breeders. They are easy to use and require no assumptions about the distribution data. This study suggested that the non-parametric stability analysis could contribute to supplementary information on the performance of hybrids and enable their recommendation to sunflower producers.

\section{ACKNOWLEDGEMENTS}

This work was supported by the Ministry of Science and Technological Development of the Republic of Serbia (Research Grant: TR-20080).

\section{REFERENCES}

Akcura, M., and Kaya, J., 2008. Nonparametric stability methods for interpreting genotype by environment interaction of bread wheat (Triticum aestivum L.). Genet. Molec. Biol. 4(31): 906-913.

Akcura, M., Kaya, J., and Tanner, S., 2009. Evaluation of durum wheat genotypes using parametric and non-parametric stability statistics. Turkish J. Field Crops 14(2): 111122.

Arshad, M., Bachsh, A., Haqqani, A.M., and Bashir, M., 2003. Genotype-environment interaction for grain yield in chickpea (Cicer arientinum L.). Pak. J. Bot. 35: 181-186.

Baker, R.J., 1988. Tests for crossover genotype-environment interactions. Can. J. Plant Sci. 68: 405-410.

Becker, H.C., and Léon, J., 1988. Stability analysis in plant breeding. Plant Breeding 101: 1-23.

Ceccarelli, S., and Grando, S., 1991. Selection environment and environmental sensitivity in barley. Euphytica 57: 157-207.

Crossa, J., 1990. Statistical analysis of multi-location trials. Adv. Agron. 45: 55-85.

de Kroon, J., and van der Laan, P., 1981. Distribution-free test procedures in two-way layots: A concept of rank-interaction. Stat. Neerl. 35: 189-213. 
Delic, N., Stankovic, G., and Konstatinov, K., 2009. Use of non-parametric statistics in estimation of genotypes stability. Maydica 54: 155-160.

Fox, P.N., Skowmand, B., Thompson, B.K., Braun, H.J., and Cormier, R., 1990. Yield adaptation of hexaploid spring triticale. Euphytica 47: 57-64.

Hühn, M., 1979. Beiträge zur Erfassung der phänotypischen Stabilität. I. Vorschlag einiger auf Ranginformationen beruhenden Stabilitätsparameter. EDV in Medizin und Biologie 10: 112-117.

Hühn, M., 1990a. Non-parametric measures of phenotypic stability. Part 1: Theory. Euphytica 47: 189-194.

Hühn, M., 1990b. Non-parametric measures of phenotypic stability. Part 2: Applications. Euphytica 47: 195-201.

Hühn, M., and Léon, J., 1985. Genotype $\times$ environment interactions and phenotypic stability of Brassica napus. Z. Pflanzenzüctg. 95: 135-146.

Hühn, M., and Nassar, R., 1989. On the tests of significance for nonparametric measures of phenotypic stability. Biometrics 45: 997-1000.

Kang, M.S., 1988. A rank-sum method for selecting high yielding stable corn genotypes. Cereal Res. Commun. 16: 113-115.

Kang, M.S., 1990. Understanding and utilization of genotype-by-environment interaction in plant breeding. In: Kang, M.S. (ed.) Genotype-by-environment interaction and plant breeding, Louisiana St. University, Agricultural Center, pp. 52-68.

Mohammadi, R., Abdulahi, A., Haghparast, R., Aghaee, M., and Rostaee, M., 2007. Nonparametric methods for evaluating of winter wheat genotypes in multi-environment trials. World J. Agric. Sci. 3:137-142.

Nassar R., and Hühn, M., 1987. Studies on estimation of phenotypic stability: tests of significance for nonparametric measures of phenotypic stability. Biometrics 43: 45-53.

Sabaghnia, N., Dehghani, H., and Sabaghpour, S.H., 2006. Nonparametric methods for interpreting genotype $\times$ environment interaction in lentil genotypes. Crop Sci. 46: 11001106.

Scapim, C.A., Oliveira, V.R., Bracinill, A.L., Cruz, C.D., Andrade, C.A,B., and Vidigal, M.C.G., 2000. Yield stability in maize (Zea mays L.) and correlations among the parameters of the Eberhart and Russell, Lin and Binns and Huehn methods. Genet. Mol. Biol. 23: 387393.

Segerloo, A.E., Sabghpour, S.H., Deghani, H., and Kamrani, M., 2008. Non-parametric measures of phenotypic stability in chickpea genotypes (Cicer arietinum L.). Euphytica 162: 221-229.

Steel, R.G.D., and Torrie, J.H. 1980. Principles and Procedures of Statistics, a Biometrical Approach. $2^{\text {nd }}$ edition. McGraw-Hill, New York, pp. 633.

Škorić, D., Joksimović, J., Jocić, S., Jovanović, D., Marinković, R., Hladni, N., and Gvozdenović, S., 2005. Ocena vrednosti produktivnih svojstava NS-hibrida suncokreta. Zbornik radova Naučnog Instituta za Ratarstvo i Povrtarstvo, Novi Sad, 41: 21-33.

Thennarasu, K., 1995. On certain non-parametric procedures for studying genotype-environment interactions and yield stability. Indian J. Genet. 60: 433-439.

Truberg, B., and Hühn, M., 2000. Contribution to the analysis of genotype be environment interactions: Comparison of different parametric and non-parametric tests for interactions with emphasis on crossover interactions. Agron. Crop Sci. 185: 267-274.

Tuba, B.B., and Dogan, S., 2006. Stability parameters in lentil. J. Cent. Eur. Agric. 7: 439-444.

Yan, W., and Hunt, L.A., 2003. Biplot analysis of multi-environment trial data. In: Kang MS (Ed.), Quantitative genetics, genomics and plant breeding. CAB Inter., Wallingsford, Oxon, UK, pp. 289-303.

Yue, G.L., Heer, W.F., Moyer, J.L., Maddux, L.D., Sorensen, E.L., and Liang, G.H. 1996. Comparison of nonparametric and parametric stability estimates to evaluate alfalfa cultivars. J. Genet Breeding 50: 67-74.

Yue, G.L., Roozeboom, K.L., Schapaugh, W.T. Jr., and Liang, G.H., 1997. Evaluation of soybean cultivars using parametric and non-parametric stability estimates. Plant Breeding 116 : 217-275. 
